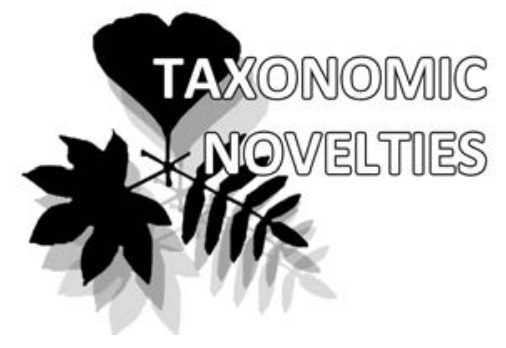

Anatoly V. Karakulov

e-mail:krk007@rambler.ru

Central Siberian Botanical Garden SB RAS, Novosibirsk, Russia

Manuscript received: 07.02.2018

Review completed: 13.05.2018

Accepted for publication: 15.05.2018

Published online: 16.05.2018

\section{A unique form of Salix schwerinii E.L. Wolf (Salicaceae Mirb.) from the Russian Far East}

\author{
Anatoly V. Karakulov
}

\begin{abstract}
A B S T R A C T
A golden form of Salix schwerinii new to the science was described from the territory of Zeya State Nature Reserve. This is the only form with golden leaves noted among all representatives of the family Salicaceae.

Ke y w o r d s : Salix schwerinit, forma aurea, new form, Far East, Amur Region

\section{P E 3 Ю M E}

Каракумов А.В. Уникамьная форма Salix schwerinii E.L. Wolf (Salicaceae Mirb.) с Аацьнего Востока России. С территории Зейского госуАарственного природного заповедника описана новая Аля науки золотистая форма Salix schwerinii. Это единственная форма с золотистыми кистьями, отмеченная среди всех представителей семейства Salicaceae.

К $\boldsymbol{\Lambda}$ ю ч е в ы е с $\mathbf{~ о ~ в ~ а : ~ S a l i x ~ s c h w e r i n i i , ~ f o r m a ~ a u r e a , ~ н о в а я ~ ф о р м а , ~ А а л ь н и и ̆ ~ В о с т о к , ~}$ Амурская область
\end{abstract}

The Salix L species comprise an important part of diversity of woody plants in Asian Russia. They occur in all natural-climatic zones over the whole area of Siberia and the Russian Far East and are represented by 103 species (Baikov 2012). Subspecies and forms of willows were distinguished and described by habit features (spreading, pyramidal, weeping, clavate), color of bark of young branches and the shape of branches (redbark, yellowbark, greenbark, flexuose) and leaf color (blue, silvery, etc.). None of the species from the genera of the family Salicaceae Lindl.: Chosenia Nakai, Salix L., Populus L. have forms with golden leaves (Komarov 1936, Sokolov 1951, Skvortsov 1968, Kolesnikov 1974, Koropachinskiy \& Vstovskaya 2002).

A new form of Salix schwerinii with golden colour of leaves (Fig. 1) was found during the field work in Zeya Nature Reserve in Amur Region. Earlier, only a weeping form had been described in this species ( $\mathrm{Ba}$ kulin et al. 2008). Herbarium specimens were collected at the foot of the Tukuringra Mountain Range, the flora of which includes 14 species of willow (Starchenko 2008, Veklich \& Darman 2013).
Salix schwerinii E.L. Wolf f. aurea A. Karakulov forma nova

A shrub up to $6 \mathrm{~m}$ tall. Young shoots are short-hairy, olive-golden, later brown, thin, brittle. Leaves are alternate, 2-12 cm long, 0.3-1.5 cm wide, lanceolate, almost linear. The margin of the blade is even, slightly curled beneath. Leaves are glabrous, shiny above, young leaves golden, later golden-green, silvery-white beneath due to dense short and accumbent pubescence. Stipules are awl-shaped, up to $3 \mathrm{~mm}$ long, quickly deciduous.

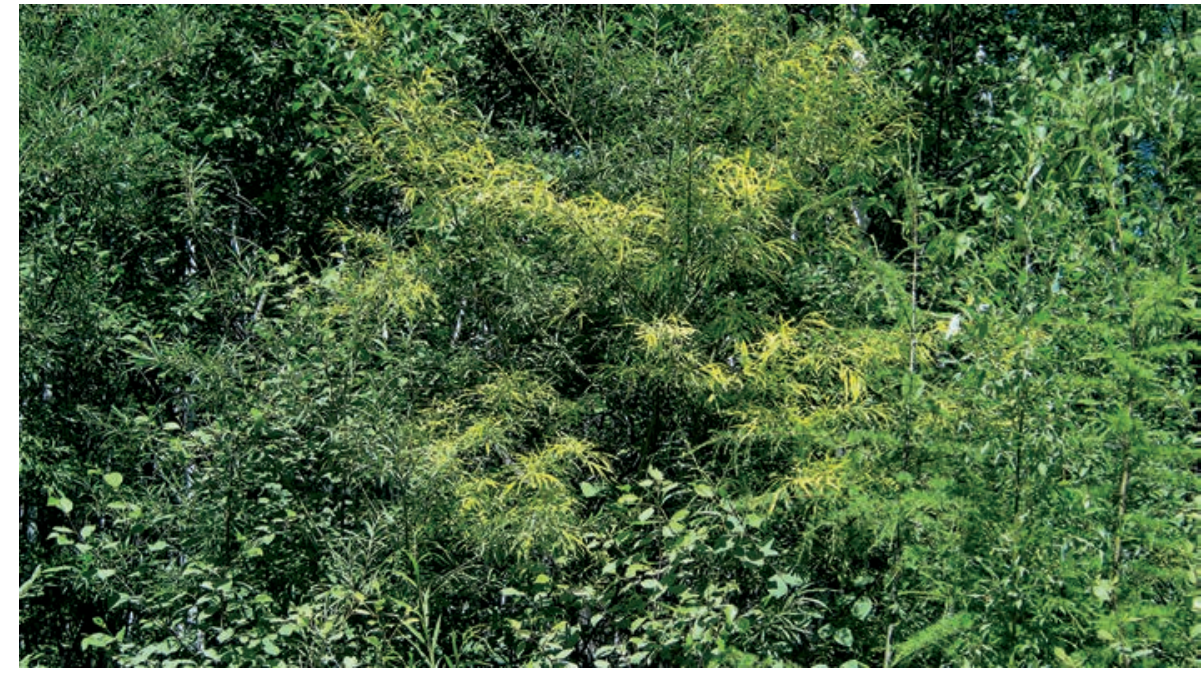

Figure 1 Salix schwerinii E.L. Wolf f. aurea A. Karakulov in natural habitat 


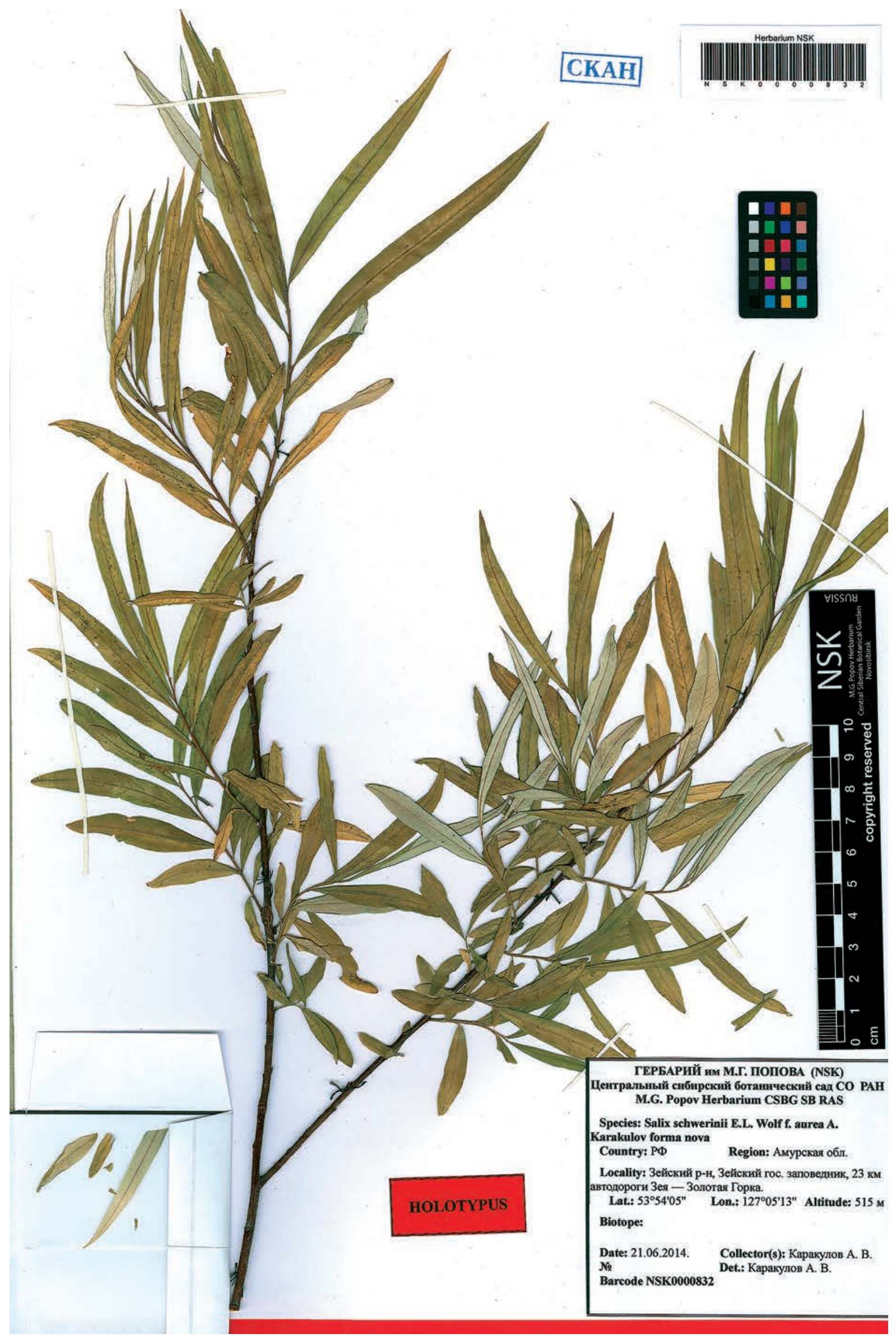

Figure 2 Type specimen of Salix schwerinii E.L. Wolf f. aurea A. Karakulov forma nova 
Type specimens: "Russia, Amur Oblast, Zeya Region, Zeya State Nature Reserve, $23 \mathrm{~km}$ of the Zeya-Zolotaya Gorka motorway, 53 $54^{\prime} 05^{\prime \prime} \mathrm{N}, 127^{\circ} 05^{\prime} 13^{\prime \prime E}$, elevation $515 \mathrm{~m}$ above sea level, 06.12.2014. Coll. \& Det. A. Karakulov. Holotypus: NSK [NSK0000832], Isotypus: NSK [NSK0000831] (Fig. 2).

A revealed golden form of Salix schwerinii occurs at the southern foot of the Tukuringra Mountain Range in the thickets of Salix schwerinii, Duschekia fruticosa (Rupr.) Pouzar and Betula pendula Roth. It is highly ornamental due to bright foliage and is of specific interest for urban plantings. It is in need of conservation.

\section{ACKNOWLEDGEMENTS}

The work was carried out within the framework of the project of Central Siberian Botanical Garden SB RAS AAAA-A17-117012610054-6 "Analysis of intraspecific structure of resource plants of Asian Russia, selection and preservation of the gene pool", No. USU 440534. When preparing the article, the materials of bioresource scientific collection of CSBG SB RAS "Herbarium of higher vascular plants, lichens and fungi (NSK)" were used, No. USU 440537. The author expresses his thanks to administration and staff of Zeya State Nature Reserve for the assistance in organization, conducting field work and collection of plant material.

\section{LITERAT URE CITED}

Baikov, K.S. (ed.) 2012. Synopsis of the flora of Asian Russia: Vascular plants. Izdatel'stvo Sibirskogo otdeleniya RAN, Novosibirsk. 640 pp. (in Russian). ККонспект фморы Азиатской России: Сосудистые растения / под реА. К.С. Байкова. Новосибирск: ИзА-во СО РАН, 2012. 640 с.].

Bakulin V. T., E.V. Banaev, T.N. Vstovskaya, T.N. Kiseleva, I.Yu. Koropachinsky, N.P. Lapteva, R.I. Loskutov, E.M. Lyakh, O.N. Potemkin \& L.N. Chindyaeva 2008. Woody plants for landscaping in Novosibirsk. Geo, Novosibirsk. 303 pp. (in Russian). [Бакулин В.Т., Банаев Е.В., Встовская Т.Н., Киселева Т.Н., Коропачинский И.Ю., Ааптева Н.П., Аоскутов Р.И., Аях Е.М., Потемкин О.Н., Чиндяева А.Н. 2008. Аревесные растения Аля озеленения Новосибирска. Новосибирск: Гео. 303 с.].

Kolesnikov, A.I. 1974. Ornamental dendrology. Lesnaya promyshlennost', Moscow. 704 pp. (in Russian). [Колесников А.И. 1974. Аекоративная дендрология. М.: Аесная промышленность. 704 с.].

Koropachinskiy, I.Yu. \& T.N. Vstovskaya. 2002. Woody plants of Asian Russia. Izdatel'stvo Sibirskogo otdeleniya RAN, Novosibirsk. 707 pp. (in Russian). [Коропачинский И.Ю., Встовская Т.Н. 2002. Аревесные растения Азиатской России. Новосибирск: ИзА-во СО РАН. 707 с.].

Skvortsov, A.K. 1968. Willows of the USSR: systematic and geographical review. Nauka, Moscow. 262 pp. (in Russian). [Скворцов А.К. 1968. Ивы СССР: систематический и географический обзор. М.: Наука. 262 с.].

Sokolov, S.Ya. (ed.) 1951. Trees and shrubs of the USSR, vol. 2. Izdatel'stvo Akademii nauk SSSR, Moscow, Leningrad. 610 pp. (in Russian). [Аеревья и кустарники СССР. 1951. / под ред. С.Я. Соколова. Т. 2. М., А.: ИзА-во Академии наук СССР. 610 с.].

Starchenko, V.M. 2008. Flora of the Amur Oblast' and issues of its conservation: the Russian Far East. Nauka, Moscow. 228 pp. (in Russian). [Старченко B.M. 2008. ФАора Амурской области и вопросы ее охраны: Аальний Восток России. М.: Наука. 228 с.].

Komarov, V.L. (ed.) 1936. Flora of the USSR, vol. 5. Izdatel'stvo Akademii nauk SSSR, Moscow, Leningrad. 762 pp. (in Russian). [ФАора СССР / поА реА. В.А. Комарова. Т. 5. M., А.: Издат-во Академии наук СССР, 1936. 762 с.].

Veklich, T.N. \& G.F. Darman. 2013. Illustrated flora of Zeya reserve. Studiya Art, Blagoveshchensk. 378 pp. (in Russian). Веклич Т.Н., Аарман Г.Ф.2013. Илмюстрированная фмора Зейского заповедника. БАаговещенск: Студия Арт. 378 с.]. 